\title{
THE NECESSITY OF GIFTED EDUCATION IN GREEK SCHOOLS
}

\author{
Eirini Papachristou ${ }^{\mathrm{i}}$ \\ Preschool Head Teacher, \\ Med, Msc, \\ Ministry of Education and Religious Affairs, \\ Greece
}

\begin{abstract}
:
Questions about gifted and talented students have from time to time concerned the scientific community, teachers and parents. It is widely accepted that additionally to high intelligence, characteristics such as creativity, but also social and emotional characteristics had to be taken into account in order to identify gifted students. Today the wide group of disabled people includes also gifted children or "high ability children". In Greece the legal framework for gifted children is incomplete. It was not until 2003 and then 2008 that a low was passed, which states that people with special skills and talents could be given special educational treatment. However, this reference has never been applied. The role of a teacher in observing, recognizing and developing the giftedness and the talent of the students is particularly important. The aim of this article is to define the gifted, talented or "high abilities" students, to describe their positive and negative characteristics, as they emerge from the recent literature and finally to report the situation that has been formed in Greece as well as the steps that need to be taken.
\end{abstract}

Keywords: gifted students, special education needs, Greece

\section{Introduction}

Giftedness has concerned society since antiquity. Questions about gifted and talented students have from time to time concerned the scientific community, teachers and parents. Many times, students with high mental abilities hide their potential in order to be accepted by their peers. Undoubtedly every education system should aim at the comprehensive development of all students. Equality in education means supporting the individual needs and particularities of all students.

The gifted and talented students fall into the category of people with special educational needs. This means that they need a differentiated educational program that

i Correspondence: email maxekp10@gmail.com 
promotes and enriches the common curriculum. Suitable educational facilities for this category of students are schools exclusively for gifted students, their integration into a regular class, the acceleration of a lesson etc. Unfortunately, the Greek educational reality is dominated by the theoretical and research deficit in issues of gifted children (Crisafidis, 2008).

For many years, the high intelligence in the test Stanford-Binet was the only characteristic of giftedness (intelligence indicator over 130). According to Tsiamis (2006), from the early 1940s an attempt was made to establish other elements of giftedness. In addition to high intelligence, characteristics such as creativity, but also social and emotional characteristics had to be taken into account in order to identify gifted students. The terms gifted and talented differ. Gifted is considered the person who shows high performance in more than one field, while talented is defined the person who shows an unusually high ability in a specialized area of human activity e.g. mathematics. Both giftedness and talent are considered to be the result of the interaction of individual characteristics on the one hand like excellent mental capacity, high motivation, creativity - enrichment trinity model (Renzulli, 2005) and on the other various aspects like family, school, media, communication etc. (Fingelkurts \& Fingelkurts, 2002).

The modern view of intelligence emerges from multidimensional theoretical models (H. Gardner, K. Heller, Fr. Gagne, J. Renzulli) which are based on the interaction and synthesis of various factors for the definition of gifted child (creativity, interests, motivations etc.).

From time to time, various definitions have been given for the giftedness, while there is disagreement among experts as to its delimitation. According to National Association for Gifted Children (NAGC), (Delisle \& Lewis, 2003, p. 35) a gifted person is someone who shows or has the ability to demonstrate an exceptional level in one or more areas of expression. Some of these skills are very general, such as leadership or the ability to think creatively. Sometimes there are very specific talents that occur in particular situations such as competence in learning, science or music.

Nowadays, the term "high ability children" is used internationally. According to this definition these are students who have the ability to cover the Curriculum at significantly faster rates and higher level of complexity than the vast majority of their classmates. That happens because of their developed knowledge, creative and cognitive abilities, predispositions, incentives and interests. As a result, "high ability children" need a differentiated educational program which promotes and enriches the curriculum, in accordance to the principles of differentiated education and the statutory requirements for specific educational provision for the categories of pupils with significant variations (Matsagouras, 2008). A lack of motivation has often been suggested to be an underlying cause of underachievement (Preckel, Holling \& Vock, 2006; Snyder \& Linnenbrink-Garcia, 2013).

Criteria for teachers to identify students as gifted are mostly based on cognitive factors (intelligence, achievement), but also non cognitive factors (motivation, personality creativity) (Endepohls-Ulpe \& Ruf, 2006, as cited in Hornstra, L,, Bakx, A., Mathijssen, S., \& Denissen, J. J. A., 2020). 


\section{Characteristics of gifted and talented children}

The problem in the educational context is the identification of gifted and talented children. In particular in pre-school and early school age, the difficulties are greater. With the pre-school age unexplored, "high ability children" make up 3-5\% of the student population (Delisle \& Lewis, 2003; Matsagouras, 2005).

But what are those elements that the gifted children display? According to Manning (2006, p. 66), one can distinguish the following positive characteristics:

- They can learn and retain a large amount of information.

- Understand concepts aimed at older people.

- They have different and intense interests.

- They have richer vocabulary and verbal ability.

- They have a quick and flexible way of thinking.

- They have the ability to complete a task from an early age.

- They perceive unusual relationships between objects or situations.

- They can generalize original ideas and provide solutions to problems.

- They are persistent with a focus on the field that interests them.

- They develop their own way of thinking.

- They learn at a younger age than their peers.

- They need freedom and independence in the learning process.

- They have a great desire to discover things that interest them.

- They structure and handle high-level concepts.

- They prefer complex tasks.

- They transfer their knowledge to new situations.

- They prefer to work alone.

- They show a strong interest in books and often learn to read at an early age.

- They are more energetic and stay focused for longer. But the gifted children may also have the following negative characteristics:

- They have a negative attitude towards learning when the environment does not favor their pursuit of interests and forces them to compromise with other choices.

- They show boredom or other behavioral problems when there are no challenges or when they are asked to learn what they already know.

- Underperformance in all learning areas when their abilities are not recognized, and appropriate activities are not planned.

- Insecurity, anxiety, isolation, aggressive behavior to deal with the rejection of the ir less gifted peers.

- Need for more attention from adults.

- Low tolerance for the less able.

- Persistent self-criticism when their work is not perfect

- Overestimation of their abilities as a result of which they set unrealistic goals and become frustrated (Karnes \& Shwedel, 1983; Davazoglou, 1999; Loxa, 2004).

In addition, gifted and talented learners show insight, imagination, amazing perception, general and special knowledge, "different" questions, spiritual speed, 
humor, sensitivity to others, hegemonic abilities, interest in contemporary issues and a strong reaction to issues that cause them injustice. They also, seem to lack concentration, but when they have been asked, they know the answer (Tannenbaum, 1991; Loxa, 2004).

If a child exhibits several of the above characteristics, an early diagnosis of giftedness should be made. These behaviors are merely indications which need to be interpreted by qualified staff. Gifted children should engage in activities intended for older children, communicate with peers like them and work in environments that can develop their uniqueness (Tannenbaum, 1991; Loxa, 2004; Brody \& Mills, 2005).

\section{Possibility and necessity to educate gifted students in the Greek school}

Today the wide group of disabled people includes also gifted children. Gifted and talented learners are considered to be in need of special programs and specialized teaching and in this sense, they are people with special educational needs (Agaliotis, 2019). It is commonly accepted that many gifted students do not realize their abilities. In Greece it was not until 2003 and then 2008, that a low was passed which states that people with special skills and talents could be given special educational treatment.

According to the law 3699/2008, article 3, paragraph 3, “...Students with special educational needs are also those students who have one or more mental abilities and talents developed to a degree that far exceeds the expectations for their age group" (Law, 3699/2008). However, this reference has never been applied.

Basic requirements for an effective process of identifying these students are the following:

- The support of the process in a specific theoretical framework.

- The documented choice of qualitative-discovery media tools.

- Effective handling of various social prejudices (Agaliotis, 2019).

The educational benefits for gifted children at school can be the following: special schools exclusively for gifted children, a gifted group of children in a traditional class, acceleration of a course or class, special classes of part-time work and groups of interests (Tsiamis, 2006). Also, further specialization, same interest groups and innovation. Differentiation is therefore required, in which one or more of the following types of special teaching arrangements are applied: enrichment, acceleration, specialization and innovation.

The above teaching interventions can be applied after individual evaluation. Especially enrichment and acceleration are considered to be the most appropriate teaching arrangements for talented students in primary school.

As Crisafidis point out (2008, p. 20), “...The school reality is complex, so that a generalized theoretical approach is not possible without the contribution of action research elements, without teachers participation".

Unfortunately, in today's Greek educational reality, the theoretical and practical deficit in issues of gifted children dominates. Especially in the Greek public school there is neither an educational framework nor differentiated teaching for these students. So, the family is trying to fill this gap, namely the need for gifted children to learn more 
quickly, their thirst for new stimuli and a variety of cognitive interests, by providing them with a host of extracurricular activities at the appropriate natural financial cost.

\section{Conclusion}

The giftedness and the talent of the child should not be hidden, because it leads to atrophy of their abilities (Tsiamis, 2006). But it must not be shown either, because then it leads to social-emotional problems. According to Matsagoura (2008), there are six factors that regulate whether students' talents will develop or weaken: family, society, school, genes, gender and luck.

In order for the gifted and talented child to be happy and satisfied for the rest of their life, their giftedness or talent must be identified and nurtured, for the benefit not only of the individual, but also for their family, for our society, and for our economy and culture. The process of recognizing gifted and talented students is difficult, both because the population is not homogeneous and because the ways in which giftedness and talent appear vary.

The education of gifted and talented students should be specialized and scientifically documented and should aim to a) provide as many opportunities as possible for gifted children in order to achieve self-fulfillment and b) to increase their social impact, since they can contribute decisively to solving various problems of contemporary world, to the production of new knowledge, to the promotion of art etc. (Agaliotis, 2019). It is remarkable that a student with high motivation and good scores at a test can have a poor overall school performance, because he is bored and feels that some lessons offer them no challenges.

It is worth noting, how important the role of the teacher is in observing, recognizing and developing the giftedness and the talent of the students. In any case, the identification of gifted students should be based on academic criteria (grades, results of tests) and on criteria based on the student's interests.

Finally, regarding the Greek educational system, there is an urgent need for: a) $A$ specialized educational framework, b) Unified tools for assessing their abilities and c) Training of teachers, so that gifted children can make the most of their potential.

\section{About the Author}

Eirini Papachristou has studied Pedagogical Sciences at National and Kapodistrian University of Athens, Greece and Applied Foreign Languages in Management and Economics. She holds two master's degrees: "Studies in Education", Hellenic Open University and "Cognitive and Motor Development", Aristotle University of Thessaloniki, Greece. She also has an annually specialization in Special Education, University of Macedonia, Greece. She has a professional experience as a Head of the Department of Environmental, Health and Cultural Education of Primary Education of Thesprotia, Greece. Except her mother tongue, Greek, she also speaks English, German and Italian. She is currently working as a School Head in Preschool Education. 


\section{References}

Agaliotis, I. (2019). Educational needs of gifted and talented students: Enrichment of programs and personalization of teaching. University notes. (In Greek).

Brody, L., \& Mills, C. (2005). Talent search research: what we have learnt? High Ability Studies, 16 (1), 97-111.

Crisafidis, K. (2005). Interdisciplinary approach to knowledge. Athens: Diptyho. (In Greek).

Davazoglou, A. (1999). Charismatic children in education. Alexandroupolis: Self publishing. (In Greek).

Delisle, J., \& Lewis, B. (2003). The Survival Guide for Teachers of Gifted Kids: How to Plan, Manage and Evaluate Programs for Gifted Youth K-12. Minneapolis: Free Spirit Publishing.

Gallagher, J. J. \& Gallagher, S. A. (1994). Teaching the Gifted Child. Boston: Allyn \& Bacon. Gallagher, J. J. (1985). Teaching the gifted child (3rd ed.). Boston: Allyn and Bacon.

Hornstra L., Bakx A., Mathijssen S. \& Denissen J. J. A. (2020). Motivating gifted and nongifted students in regular primary schools: A self-determination perspective. Learning and Individual Differences, doi.org/10.1016/j.lindif.2020.101871

Law No 3699 FEK A 199/2.10.2008. Special Education and training for persons with disabilities or special educational needs https://www.kodiko.gr/nomologia/document navigation/142858/nomos-36992008. Accessed 25/09/2020. (In Greek).

Loxa, I. (2004). Guide for students with special mental abilities and talents. Athens. (In Greek). Matsagouras, E. (2005). The Einstein candidates of the school. "Kathimerini" Newspaper. (2005, April 29th).

Matsagouras, E. (2008). Educating Children with High Learning Skills: Differentiated Coeducation. Athens: Gutenberg.

Karnes, M. B., \& Shwedel, A. M. (1983). Assessment of pre-school giftedness. In D. Paget \& B. A. Bracken (Eds), The psychoeducational assessment of pre-school children (pp. 473509). New York: Grune \& Stratton.

Tsiamis. A. (2006). Charismatic children live among us. Athens: Grigoris (in Greek).

Fingelkurts, A., \& Fingelkurts, A. (2002). Exploring Giftedness. In S. P. Shohov (Ed.) Advances in Psychology Research, Vol. 9 (pp. 137-155). New York: Nova Publishers.

Manning, S. (2006). Recognizing Gifted Students: A practical Guide for Teachers. Kappa Delta Pi Record, 66.

Preckel, F., Holling, H., \& Vock, M. (2006). Academic underachievement: Relationship with cognitive motivation, achievement motivation, and conscientiousness. Psychology in the Schools, 43, 401-411. https://doi.org/10.1002/pits.20154.

Renzulli, J. S. (2005). The three-ring conception of giftedness: A developmental model for promoting creative productivity. In R. J. Sternberg \& J. Davidson (Eds.), Conceptions of giftedness (pp. 217-245)., 2nd ed. Boston, MA: Cambridge University Press.

Snyder, K. E., \& Linnenbrink-Garcia, L. (2013). A developmental, person-centered approach to exploring multiple motivational pathways in gifted 

underachievement.
Educational
Psychologist,
$48(4)$,
209-228.

https://doi.org/10.1080/00461520.2013.835597.

Tannenbaum, A. J. (1991). The Social Psychology of Giftedness. In N. Colangelo (Ed.), Handbook of Gifted Education. Boston: Allyn and Bacon.

Creative Commons licensing terms

Authors will retain the copyright of their published articles agreeing that a Creative Commons Attribution 4.0 International License (CC BY 4.0) terms will be applied to their work. Under the terms of this license, no permission is required from the author(s) or publisher for members of the community to copy, distribute, transmit or adapt the article content, providing a proper, prominent and unambiguous attribution to the authors in a manner that makes clear that the materials are being reused under permission of a Creative Commons License. Views, opinions and conclusions expressed in this research article are views, opinions and conclusions of the author(s). Open Access Publishing Group and European Journal of Special Education Research shall not be responsible or answerable for any loss, damage or liability caused in relation to/arising out of conflict of interests, copyright violations and inappropriate or inaccurate use of any kind content related or integrated on the research work. All the published works are meeting the Open Access Publishing requirements and can be freely accessed, shared, modified, distributed and used in educational, commercial and non-commercial purposes under a Creative Commons Attribution 4.0 International License (CC BY 4.0). 